FACTA UNIVERSITATIS

Series: Economics and Organization Vol. 18, № 2, 2021, pp. 117 - 134

https://doi.org/10.22190/FUEO210402010D

Original Scientific Paper

\title{
ANALYSIS OF LIMITATIONS OF ISO STANDARDS IMPLEMENTATION FROM THE EXTERNAL STAKEHOLDERS' POINT OF VIEW
}

\author{
UDC 006.83
}

\section{Edisa Dreković*, Marija Radosavljević, Melisa Bejtović*}

University of Niš, Faculty of Economics, Serbia

\begin{abstract}
The purpose of this paper is to identify key limitations of the implementation of ISO 9001:2015 standard, their correlations, as well as the connection with the problems that companies face. The paper in literature review used the research papers of other researchers related to the limitations of the implementation of ISO standards. In order to realize the purpose of the research, empirical research was conducted. The research was realized by the method of a survey questionnaire, on the sample of 12 respondents, experts of consulting companies for the implementation of standards and lead auditors of accredited certification bodies for the implementation of ISO standards in Serbia. Using this approach based on external source ensures a certain level of objectivity. Also, the experience of the respondents based on the implementation of a process approach and certification of various organizations provides the necessary credibility and quality of the research itself. The paper identifies 12 limitations of implementation ISO 9001. The results of the research show that non-material limitations are the dominant obstacle to the implementation of ISO 9001:2015. Also, those limitations are positively correlated with each other, so they can cause multiple problems for companies in fulfilling the requirements of ISO standards.
\end{abstract}

Key words: process approach, ISO 9001, limitations, problems, solutions, empirical research.

JEL Classification: L15, M11

Received April 02, 2021 / Accepted May 14, 2021

${ }^{*} \mathrm{PhD}$ Student at University of Niš, Faculty of Economics

Corresponding author: Marija Radosavljević

University of Niš, Faculty of Economics, Trg kralja Aleksandra Ujedinitelja 11, 18000 Niš, Serbia

E-mail: marija.radosavljevic@eknfak.ni.ac.rs 


\section{INTRODUCTION}

Process approach is a necessary condition for successful business of a modern company. Efficient and effective business process management ultimately ensures the creation of added value (for the company and its owners, users of products and services, employees, suppliers and all other stakeholders), increases competitive advantage, reduces business costs, improves product and service quality. Business process management is the core of quality management. In order to talk about quality of business processes in general, it is necessary to consider the standards that define quality. Globally, currently widely accepted quality management system is based on ISO 9001:2015 standard. All ISO 9001:2015 requirements are generic and can be applied in any organization, regardless of its type or size, or the products and services that organization provides. According to the latest ISO report for 2019 (published in September 2020, on the website www.iso.org), the total number of valid certificates at the global level shows that 883521 organizations are certified according to the ISO 9001:2015 standard, the second most important is ISO 14001 standard.

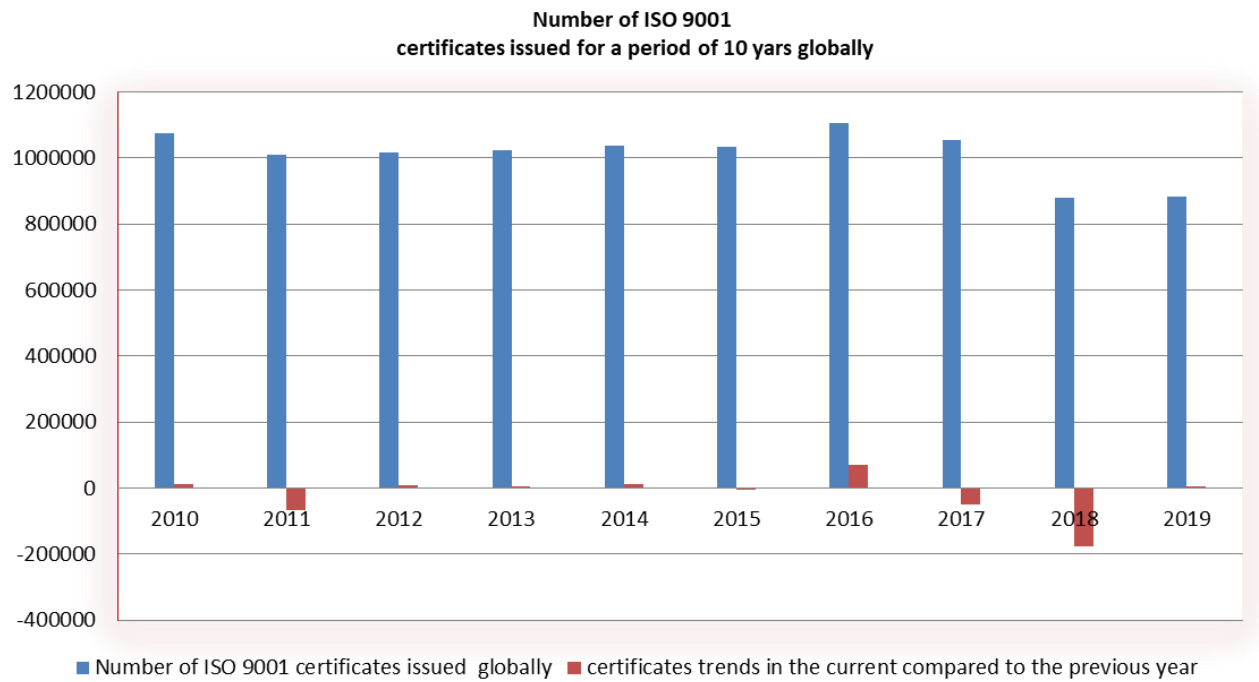

Graph 1 Number of ISO 9001 certificates issued for period of 10 years globally. Source: Committee Survey results before 2018 (iso.org)

The chart of issued ISO 9001 certificates at the global level over a period of 10 years (Graph 1) shows a significant process of desertification according to ISO 9001:2015, after the last revision of this standard. The International Organization for Standardization explained the decrease in the number of certificates issued by the insufficient participation of certification bodies in annual reporting.

The countries with the most issued ISO 9001:2015 certificates according to the ISO 2019 Report are: China, Italy, Germany, India, Japan, Spain, Great Britain, France, USA and Brazil. In these 10 countries, 69\% of ISO 9001:2015 certificates have been issued globally. When the subject of comparison are those European countries that have the most certified organizations according to ISO 9001:2015, the following can be noticed: in 
Italy, the most issued certificates are in the field of services, wholesale and retail trade, construction, basic metal \& fabricated metal products. Germany has the most certified organizations in basic metal \& fabricated metal products, electrical and mechanical industry, trade, education and information technology. In Spain, these are construction, services, manufacturing, education and information technology. The UK has the most certified companies in basic metal \& fabricated metal products, construction, trade and service industries. As far as Serbia is concerned, the leading activities are wholesale and retail trade, construction, manufacturing, services, education and information technology. It can be seen from the same database that Serbia had a loss of certificates in 2012 by $15 \%$, while in 2017 the loss of certificates was $27 \%$. In the last two years, there has been a slight growth of certified organizations.

\section{The number of ISO 9001 certificates issued in Serbia}

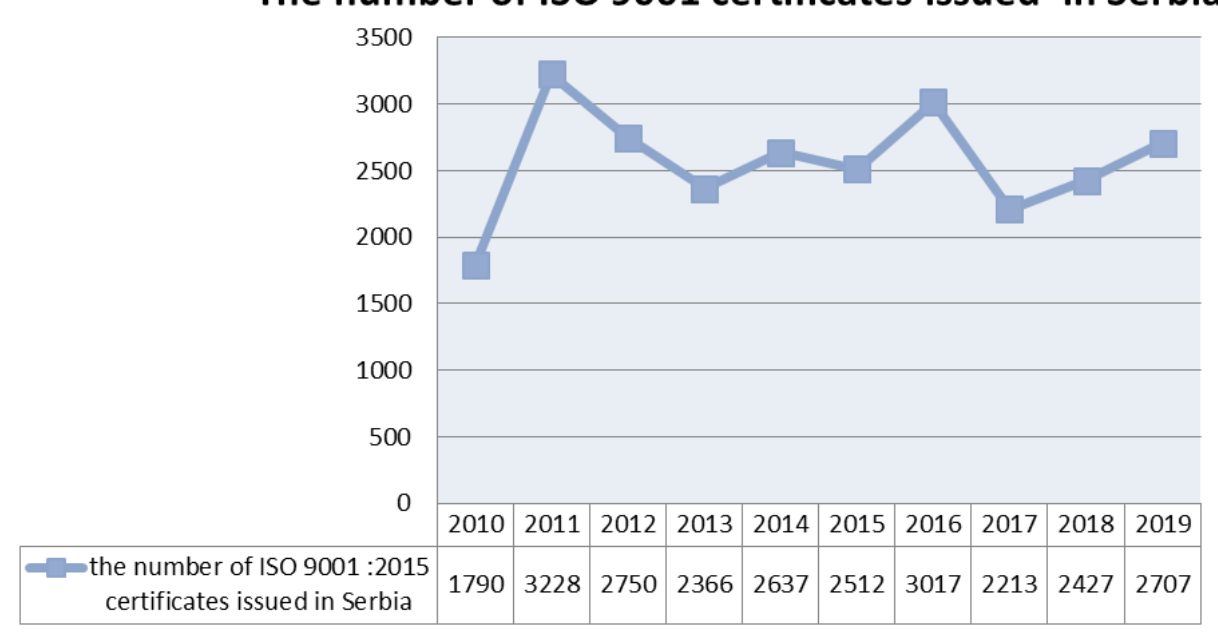

Graph 2 Number of ISO 9001 certificates issued in Serbia

Source: Committee Survey results before 2018 (iso.org), Committee 09. ISO Survey of certifications to management system standards - Full results

Comparing Serbia to the countries in the region that have a certification system according to ISO 9001:2015, it can be noticed that Serbia does not differ significantly in the number of certificates issued, nor in the trend of certification. There are numerous and diverse reasons why companies are abandoning the certification of quality systems according to ISO 9001:2015. The reasons are undoubtedly related to the reasons for implementation and the limitations that companies encounter during implementation, which are not completely eliminated, but are only emphasized and complicated through the implementation.

\section{LITERATURE REVIEW}

During the implementation of the management system according to the requirements of the ISO 9001:2015 standard, organizations face certain limitations. These limitations have been studied by many authors. The theoretical part of the paper is based on the 
analysis of the limitations of enterprises in general, because the literature concerning specific limitations in SMEs is not particularly available.

Talib and Rahman (2015) identified the following three groups of key barriers to TQM in the services sector and their impact on the implementation of ISO 9001:

1. „Barriers based on managerial issues - the most significant are the following: lack of top-management commitment, lack of coordination between departments, no benchmarking, poor planning, lack of communication,

2. Barriers based on people-oriented issues - lack of proper training and education, human resources barrier, employee resistance to change, inadequate use of empowerment and teamwork,

3. Barriers based on organizational issues - high turnover and absenteeism at the management level creates afflictions and nuisances in many organizations, attitude of employees towards quality, the lack of a continuous improvement culture."

Othman et al. (2019) identified and ranked TQM management factors influencing the successful completion and sustainable construction of projects based on the Index of Relative Importance (RII) and the correlation between clients, consultants and contractors in the Malaysian construction industry. These factors are:

1. "Management commitment,

2. Employee related,

3. Customer related,

4. Organizational culture,

5. Communication related,

6. Strategic planning,

7. Teamwork,

8. Continuous improvement."

Bounabri et al. (2018) in an empirical study on Barriers to ISO 9001 implementation Moroccan organizations, which included 115 companies, gave the following restrictions in implementation ISO 9001:

1. "Resistance to change,

2. Poor interdependence between departments,

3. Lack of top management commitment,

4. Dominance of bureaucracy,

5. Lack of internal communication among staff and between staff and top management,

6. Insufficient requirements diffusion to all organizational levels,

7. Lack of trainings,

8. Difficulty in changing culture,

9. Difficulty in process identification and management."

According to a survey conducted by Gul Polat et al., (2011) on a sample of 80 Turkish construction companies, the following limitations for ISO 9001 successful implementation are identified:

1. "Lack of top management commitment,

2. Lack of top management support,

3. Lack of top management leadership,

4. Difficulties in mapping processes and developing standardized procedures,

5. Difficulties in taking corrective and preventive actions,

6. Difficulties in employing statistical quality control techniques in construction process,

7. Lack of workforce qualified in quality management implementations,

8. Lack of effective teams / team building skills, 
9. Difficulties in including quality measures, continuously monitoring and controlling construction processes,

10. Need for employing skilled workforce,

11. Difficulties in developing quality information systems in construction process,

12. Difficulties in quantifying cost of poor quality,

13. Increases in paperwork,

14. Difficulties in finding workers, who can claim to be experts in both construction and quality,

15. Need for conducting continuous training programs for employees,

16. Difficulties in quantifying cost of quality,

17. High cost of developing and utilizing a quality management system,

18. Incompatibility of standardized quality management systems with the construction industry."

Sadikoglu and Olcay (2014) identified the following limitations on the implementation of ISO 9001 on a sample of 150 Turkish companies:

1. "Lack of employee involvement,

2. Inadequacy of the firm structure and lack of the resources,

3. Illiteracy and unawareness among the employees,

4. Constraints of the industry/market,

5. Inaccuracy and assessment difficulty in the process planning,

6. Inadequacy in the leadership comprehension,

7. Lack of understanding the importance of continuous improvement,

8. Discrepancies among customers' expectations,

9. Difficulty in the TQM structure,

10. Lack of the suppliers' support."

Sanchez-Lizarraga et al., (2020), on a sample of 172 organizations in exploratory analysis in the manufacturing sector in Mexico identified implementations barriers for ISO 9001 standard:

1. "Not demanded by the customers,

2. High investment,

3. The company manages a better QMS than ISO 9001,

4. Unnecessary for the industry,

5. Bureaucratic paper work,

6. Other reasons.“"

Almeida et al., (2018) the authors of an empirical study of Brazilian companies in the automotive supply chain, on a sample of 47 suppliers, identified the following implementation barriers for ISO 9001:

1. "Top management commitment,

2. Team commitment,

3. Training,

4. Responsibilities and authorities defined,

5. Schedule for implementation,

6. Quality culture,

7. Resources' availability,

8. Integration between departments,

9. Un-bureaucratic management system,

10. People awareness regarding the ISO 9001 significance." 
Bounabri et al., (2018) gave a wide overview of the barriers that authors dealing with this issue in different countries have defined as shown in Table 1.

Table 1 Systematic review of ISO 9001 implementation barriers

\begin{tabular}{|c|c|c|c|}
\hline Authors & Research method & Country and sample & Identified Barriers \\
\hline $\begin{array}{l}\text { Burcher, Lee \& } \\
\text { Waddell (2010) }\end{array}$ & Questionnaire & $\begin{array}{l}129 \text { Australian and } \\
175 \text { British } \\
\text { companies }\end{array}$ & $\begin{array}{l}\text { Three main difficulties were identified for an } \\
\text { organization when implementing quality } \\
\text { initiatives in Australia: } \\
\text { - Communication } \\
\text { - Organizational inertia } \\
\text { - Commitment. } \\
\text { While in Britain, commitment was singled out as } \\
\text { the most significant factor }\end{array}$ \\
\hline $\begin{array}{l}\text { Kumar \& } \\
\text { Balakrishnan } \\
(2011)\end{array}$ & Questionnaire & $\begin{array}{l}100 \text { contractors } \\
\text { from UAE }\end{array}$ & $\begin{array}{l}\text { - Leadership related issues } \\
\text { - Strategy Related Issues } \\
\text { - Quality System related issues } \\
\text { - Society oriented gaps }\end{array}$ \\
\hline $\begin{array}{l}\text { Al-Najjar \& } \\
\text { Jawad (2011) }\end{array}$ & $\begin{array}{l}\text { Questionnaire } \\
\text { survey }\end{array}$ & $\begin{array}{l}42 \text { companies in } \\
\text { Iraq }\end{array}$ & $\begin{array}{l}\text { - Top management commitment } \\
\text { - employee resistance } \\
\text { - Difficulty of performing internal audits } \\
\text { - Requirements of the standards are unrealistic }\end{array}$ \\
\hline Willar (2012) & $\begin{array}{l}\text { Questionnaire } \\
\text { survey }\end{array}$ & $\begin{array}{l}77 \text { companies in } \\
\text { Indonesia }\end{array}$ & $\begin{array}{l}\text { - ISO } 9001 \text { being a matter of fulfilling audit } \\
\text { requirements } \\
\text { - Misleading QMS purposes } \\
\text { - Lack of a well-design reward system }\end{array}$ \\
\hline $\begin{array}{l}\text { Mosadeghrad } \\
\text { (2014) }\end{array}$ & Literature review & $\begin{array}{l}54 \text { empirical } \\
\text { studies wordwide }\end{array}$ & $\begin{array}{l}\text { - Insufficient education and training } \\
\text { - Lack of employees' involvement } \\
\text { - Lack of top management support } \\
\text { - Inadequate resources } \\
\text { - Deficient leadership } \\
\text { - Lack of a quality-oriented culture } \\
\text { - Poor communication } \\
\text { - Lack of a plan for change } \\
\text { - Employee resistance }\end{array}$ \\
\hline $\begin{array}{l}\text { Jayasundara \& } \\
\text { Rajini (2014) }\end{array}$ & $\begin{array}{l}\text { Questionnaire } \\
\text { survey }\end{array}$ & $\begin{array}{l}10 \text { ISO } 9001 \text { well } \\
\text { experienced } \\
\text { professionals, in } \\
\text { Sri Lanka }\end{array}$ & $\begin{array}{l}\text { - Lack of top management involvement during } \\
\text { the implementation process' } \\
\text { - Unwillingness of employees to change work } \\
\text { systems } \\
\text { - Weak interdepartmental relations } \\
\text { - Employee resistance }\end{array}$ \\
\hline $\begin{array}{l}\text { Talib \& } \\
\text { Rahman (2015) }\end{array}$ & Literature review & General & $\begin{array}{l}\text { - Lack of communication } \\
\text { - Lack of top-management commitment } \\
\text { - Employee's resistance to change } \\
\text { - Lack of coordination between departments }\end{array}$ \\
\hline
\end{tabular}

Source: Adapted according to - Implementation in Moroccan Organizations: Empirical Study, Noussaiba Bounabri, Ahmed Amine El Oumri, Elmadani Saad, Latifa Zerrouk, Amina Ibnlfassi, Journal of Industrial Engineering and Management, page 38

Sfakianaki and Kakouris (2020) explored barriers to ISO 9001 certification for SMEs in the Greek food and beverage industry $(\mathrm{F} \& \mathrm{~B})$ and concluded that the most common are bureaucracy, lack of senior management guidance, time and resource requirements, and employee response. 
Very important implementation barriers for ISO 9001 are lack of involvement of top management, insufficient personnel qualifications, and employees' resistance to change, lack of knowledge and skills to implement TQM, and limited financial resources (Sampaio et al., 2014; Sfakianaki and Kakouris, 2020; Berrouiguet 2013).

Also the most frequent obstacles to ISO 9001 certification referred to in the literature are the cost of the QMS certification process, adaptation to the standard during implementation, employee resistance to change, qualification of human resources, employees' available time, the quantity of documentation required, top management involvement, compatibility of the standard with the activity sector (Ferreira \& Candido, 2021). Willar et.al, (2015) identified issues of management attitude and purpose as barriers that may affect effective QMS implementation. The involvement of top management and the active participation of all employees are key factors for certification renewal, in the absence of which the company may not be able to renew its certificate (Sampaio et al., 2014).

The critical barriers for the successful implementation of TQM also can be inappropriate planning of TQM implementation program, lack of financial support, lack of employee training, lack of empowerment of employees, lack of sufficient physical resources (Talapatra \& Uddin, 2019).

The basis for the successful implementation of ISO standards is a supportive environment (supportive leadership, culture, and structure), and the main obstacles are related to management and leadership. In this context, strategic problems are significant barriers to TQM implementation and have the most negative impact on its success. These are strategic barriers, structural barriers, human resource barriers, contextual barriers, and procedural barriers (Mosadeghrad, 2014). The environment where ISO standards are applied largely defines the key barriers to implementation. This is especially the case with an ethically poor business environment. Therefore, the barriers such as the lack of quality support, poor TQM knowledge and TQM awareness, poor information sharing, temporary workers, overdependence on contract document, poor data collection measurement, undefined TQM roles and responsibilities, award to lowest bidder tendency, poor business environment, and corruption are common (Dilawo \& Salimi, 2019). Looking at the health services sector, in addition to barriers that occur in other SME sectors, there are other obstacles: high employee turnover, resistance to change among employees, bureaucracy and hierarchical structure, professional autonomy, tensions between managers and professionals, and difficulties in evaluating health processes and outcomes (Alsughayir 2014; Mosadeghrad 2013). Some authors consider barriers to be difficulties and divide them into difficulties related to employees, difficulties associated with structuring the quality management system, integration difficulties, and difficulties arising from planning (Anholon et al.,2018).

Based on the literature review, it can be said that certain research is based on case studies, while others involved sample based statistical analysis. Also, most of the research concerns the survey of companies, more precisely their representatives, but there are also surveys that are based on the examination or experts. In any case, a systematic review of the literature is a useful tool to formulate initial hypotheses and trace research directions. The literature review is the basis for the development of a survey questionnaire for the implementation of the empirical part of the research. 


\section{RESEARCH METHODOLOGY}

Although it is evident that the implementation of process approach and the establishment of appropriate management systems, aimed at improving quality, has a positive impact on business performance, the trend of desertification and a significant list of limitations in the implementation of management systems according to ISO 9001:2015 indicate the need for more detailed analysis, especially for small and medium enterprises (SMEs). In this sense, the purpose of the paper is to identify key limitations, their correlations, as well as the connection between limitations and problems that companies face. In order to realize the purpose of the research, empirical research was conducted.

Research related to the implementation of process approach to ensure business excellence has a major limitation that is reflected in the subjectivity of the respondents, regardless of the research method used. Especially since the respondents are mostly from the managerial structure of the company (top managers, quality managers). Using an approach based on external source ensures a certain level of objectivity. Also, the experience of the respondents based on the implementation of a process approach and certification of various organizations provides necessary credibility and quality of the research itself. The research was realized by the survey questionnaire method on a sample of 12 respondents, including consulting companies' experts for the implementation of standards and lead auditors of accredited certification bodies for the implementation of ISO standards in Serbia, according to the Accreditation Body of Serbia (ATS). In order to achieve the purpose of the research, the paper tested several hypotheses:

H1: Non-material limitations compared to material have a greater impact on the success of the implementation of ISO 9001 standards,

H2: Most of the limitations faced by organizations in the implementation of ISO 9001 standards are positively correlated with each other,

H3: Limitations in the implementation of ISO 9001 lead to problems in fulfilling the requirements of the ISO 9001 standard.

Analyzing the literature review, the limitations of implementing ISO 9001 standards in organizations can be classified as:

1. Lack of commitment of top management to the management system based on the processes and requirements of ISO 9001:2015,

2. Unclearly defined company strategies and goals,

3. Non-involvement of employees who are the bearers of the process in defining strategies and goals (centralized decision-making),

4. Resistance to change,

5. Inadequate internal communication between employees, also between employees and managers,

6. Lack of innovation and continuous learning,

7. Insufficient professional knowledge of the process bearers,

8. Lack of human resources management (HRM),

9. Lack of finance for implementation and certification according to the requirements of ISO 9001:2015,

10. Lack of adequate information system,

11. Inadequate customers and suppliers' databases,

12. Insufficient capabilities and skills of those employees who are key to quality (creativity, teamwork, critical thinking, emotional intelligence, negotiation, ability to solve complex problems). 
These limitations represent a key segment of the survey questionnaire for experts. Certainly, for the purpose of complete analysis and testing of all hypotheses, a questionnaire included the questions that refer to the problem in fulfilling the requirements of the ISO 9001 standard, as well as questions concerning the capability of employees and ways of solving problems. Other questions that were part of the questionnaire were presented through the analysis of research results. To test the hypothesis, the collected data have been analyzed using the statistical analysis methods. In doing so, the following methods have been applied: descriptive statistics and correlation analysis, hierarchical cluster analysis.

\section{RESEARCH RESULTS}

The research was conducted in the period from December 22nd 2020 to February 11th 2021. Questionnaires were sent to the addresses of 30 consulting companies for the implementation and evaluation of ISO 9001:2015. The feedback was received from 12 consultants and lead auditors, which means that the response rate was $40 \%$. The questionnaire is divided into general questions, the main questions of identifying limitations, the problems that limitations cause and the solutions.

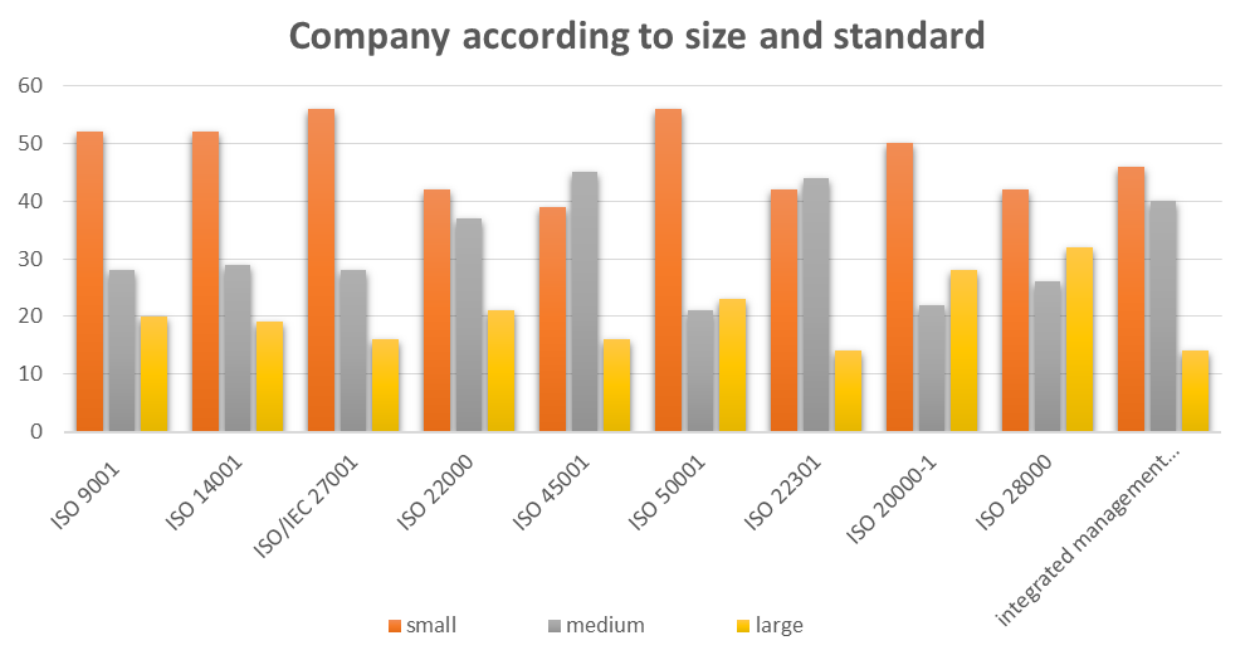

Graph 3 Companies by size that were subject to implementation and certification according to the requirements of ISO standards

Source: Author's calculation

According to the answers, all respondents participated in the implementation of ISO 9001 standards and integrated management systems. 88\% of them participated in the implementation of ISO / IEC27001, followed by ISO14001 and 77\% of ISO $45001.33 \%$ of them participated in the implementation of ISO 20000-1 and ISO 28000. Respondents applied the ISO 9001 standard in small enterprises in Serbia 52\%, 28\% were medium, 20\% large enterprises. Thus, the answers of the respondents mainly refer to their experiences in the implementation of ISO 9001 standards in the SME sector in Serbia, which is the subject of this paper. In the survey of experts, answers were sought that refer only to the SME 
sector. The questionnaire defined 12 limitations for the implementation of ISO 9001. The limitations are classified into two groups, non-material and material. The only material limitation relates to the lack of finance for implementation and certification according to the requirements of ISO 9001:2015. Non-material limitations are defined as:

1. Limitations of human capital - lack of commitment of top management to the management system based on processes and requirements of ISO 9001: 2015, unclear defined company strategy and goals, insufficient professional knowledge of the process holder,

2. Limitations of structural capital - lack of human resource management (HRM), lack of adequate information system, inadequate customers and suppliers' database,

3. Limitations concerning organizational culture - non-involvement of employees who are the bearers of the process in defining strategies and goals (centralized decision-making), resistance to change, inadequate internal communication between employees and between employees and managers, lack of innovation and continuous learning,

4. Limitation of insufficient capabilities and skills of those employees who are key to quality (creativity, teamwork, critical thinking, emotional intelligence, negotiation, ability to solve complex problems).

Table 2 Descriptive statistics: Limitations

\begin{tabular}{lccccc}
\hline & $\mathrm{N}$ & Minimum & Maximum & Mean & Std. Deviation \\
\hline $\mathrm{O} 1$ & 12 & 1.00 & 5.00 & 4.0833 & 1.24011 \\
$\mathrm{O} 2$ & 12 & 2.00 & 5.00 & 3.6667 & .77850 \\
$\mathrm{O} 3$ & 12 & 2.00 & 5.00 & 3.5000 & 1.08711 \\
$\mathrm{O} 4$ & 12 & 1.00 & 5.00 & 2.2500 & 1.21543 \\
$\mathrm{O} 5$ & 12 & 1.00 & 5.00 & 2.6667 & 1.23091 \\
$\mathrm{O} 6$ & 12 & 1.00 & 4.00 & 2.6667 & 1.15470 \\
$\mathrm{O} 7$ & 12 & 3.00 & 5.00 & 4.2500 & .75378 \\
$\mathrm{O} 8$ & 12 & 3.00 & 5.00 & 4.1667 & .57735 \\
$\mathrm{O} 9$ & 12 & 2.00 & 5.00 & 3.1667 & .93744 \\
$\mathrm{O} 10$ & 12 & 2.00 & 5.00 & 3.7500 & 1.21543 \\
O11 & 12 & 1.00 & 4.00 & 3.0833 & .79296 \\
O12 & 12 & 1.00 & 3.00 & 2.1667 & .71774 \\
\hline \multicolumn{5}{c}{ Source: Author's calculation } \\
\end{tabular}

Descriptive statistics analysis from Table 2 shows that the highest average mean by respondents was assigned to the following limitations: Non-involvement of employees who are process bearers in defining strategies and goals (centralized decision making) O7 (Mean 4.2500), Resistance to change - O8 (Mean 4.1667), Lack of commitment of top management to the management system based on processes and requirements ISO 9001:2015 - O1 (Mean 4,0833).

The low value of the standard deviation in these three defined limitations shows that the answers of the respondents do not differ significantly from each other. This actually points to the conclusion that respondents agreed that organizational culture is a key limitation for the application of ISO 9001 in enterprises. Group of limitations related to 
intellectual capital (human, structural) average score 3.1389 with a larger difference in the answers of respondents (average standard deviation 1.1178) compared to a group of limitations related to organizational culture (Mean 3.833, Std. deviation 0.871). When it comes to the limitations of human and structural capital and their impact on the implementation of ISO 9001 in SMEs, according to the results, human capital is a larger limitation (Mean 3,7501, Std. deviation 1,03524) compared to structural capital (Mean 2, 5278, Std. deviation 1,2003). Limitation of insufficient capabilities and skills of those employees who are key to quality (creativity, teamwork, critical thinking, emotional intelligence, negotiation, ability to solve complex problems) $\mathrm{O} 11$ is according to the answers of respondents with a Mean of 3.0833, Std. deviation 0.79296 are proved to be a significant limiting factor in the implementation of ISO standards, immediately after the inadequate organizational culture and lack of intellectual capital. Limitation O12 according to the data in Table 2 with a Mean of 2.1667 with a small difference in the respondents' answers (Std. deviation 0.71774) shows that financial capital is the factor that least affects the implementation of ISO standards. Thus, the statement defined in hypothesis H1 is confirmed.

Respondents were asked to evaluate the capabilities of employees that most affect the success of the implementation of ISO 9001 in the company, and the results are presented in Table 3.

Table 3 Descriptive Statistics - Employees' capabilities

\begin{tabular}{lccccc}
\hline & $\mathrm{N}$ & Minimum & Maximum & Mean & Std. Deviation \\
\hline $\mathrm{SZ1}$ & 12 & 2.00 & 5.00 & 3.2500 & 1.13818 \\
$\mathrm{SZ2}$ & 12 & 2.00 & 4.00 & 3.4167 & .90034 \\
$\mathrm{SZ3}$ & 12 & 1.00 & 5.00 & 3.4167 & 1.31137 \\
$\mathrm{SZ4}$ & 12 & 2.00 & 5.00 & 4.0000 & .95346 \\
$\mathrm{SZ5}$ & 12 & 2.00 & 5.00 & 4.3333 & .98473 \\
$\mathrm{SZ6}$ & 12 & 1.00 & 5.00 & 3.2500 & 1.28806 \\
$\mathrm{SZ7}$ & 12 & 3.00 & 5.00 & 4.2500 & .86603 \\
$\mathrm{SZ8}$ & 12 & 1.00 & 5.00 & 2.9167 & 1.08362 \\
$\mathrm{SZ9}$ & 12 & 2.00 & 4.00 & 3.1667 & .93744 \\
$\mathrm{SZ10}$ & 12 & 3.00 & 5.00 & 4.0833 & .51493 \\
\hline \multicolumn{5}{c}{ Source: Author's calculation }
\end{tabular}

The most evaluated capability is cooperation with others SZ5 (4.3333 respondents' answers do not differ significantly), then logical reasoning and decision-making SZ7, then cognitive flexibility SZ10, communication skills SZ4. The least important for the success of the implementation by respondents were negotiating SZ9 (3.1667) and service orientation SZ8 (2.9167).

Since organizations are complex holistic systems, the problems they face are mutually correlated. In that sense, a correlation analysis of the observed limitations of the implementation of the ISO series standards was performed. Regarding the correlation between limitations, the correlation analysis shows that the O1 limitation, defined as the lack of commitment of top management to the management system based on processes and requirements of ISO 9001:2015, is positively correlated with the O7, limitation noninvolvement of employees in the process (centralized decision making). This actually indicates that if the responsibility does not come from the top of the organization and if 
authorizations and responsibilities are not fully defined and assigned to all levels of management, quality has no chance. Also, a correlation coefficient of 0.621 clearly indicates that lack or inadequate use of human capital personified in lack of commitment top management of QMS and the lack of financial capital personified in the lack of finance for implementation and certification according to the requirements of ISO 9001:2015 may actually threaten the success of the implementation of this standard in the SME sector in Serbia. A correlation coefficient of 0.586 for $\mathrm{O} 2$ shows a positive correlation between the limitation of unclearly defined company strategy and goals and the limitation of noninvolvement of employees who are the bearers of the process in defining strategies and goals (centralized decision-making).

Table 4 Correlation between limitations

\begin{tabular}{|c|c|c|c|c|c|c|c|c|c|c|c|c|c|}
\hline & & $\mathrm{O} 1$ & $\mathrm{O} 2$ & $\mathrm{O} 3$ & $\mathrm{O} 4$ & O5 & O6 & $\mathrm{O} 7$ & O8 & O9 & $\mathrm{O} 10$ & O11 & $\mathrm{O} 12$ \\
\hline \multirow[t]{3}{*}{$\mathrm{O} 1$} & $\mathrm{CC}$ & 1.000 & .356 & -.308 & -.199 & -.080 & -.483 & $.585^{*}$ & .285 & .302 & -.503 & -.446 & $.621^{*}$ \\
\hline & Sig. & & .256 & .329 & .536 & .806 & .112 & .046 & .368 & .341 & .095 & .146 & .031 \\
\hline & $\mathrm{N}$ & 12 & 12 & 12 & 12 & 12 & 12 & 12 & 12 & 12 & 12 & 12 & 12 \\
\hline \multirow[t]{3}{*}{$\mathrm{O} 2$} & $\mathrm{CC}$ & .356 & 1.000 & .120 & .174 & .093 & .246 & $.586^{*}$ & -.260 & .340 & -.125 & -.090 & .524 \\
\hline & Sig. & .256 & & .711 & .590 & .773 & .442 & .045 & .414 & .280 & 699 & .781 & .080 \\
\hline & $\mathrm{N}$ & 12 & 12 & 12 & 12 & 12 & 12 & 12 & 12 & 12 & 12 & 12 & 12 \\
\hline \multirow[t]{3}{*}{$\mathrm{O} 3$} & $\mathrm{CC}$ & -.308 & .120 & 1.000 & .509 & .536 & .573 & .398 & .302 & .208 & .557 & .253 & -.236 \\
\hline & Sig. & .329 & .711 & & .091 & .072 & .052 & .200 & .340 & .516 & .060 & .427 & .460 \\
\hline & $\mathrm{N}$ & 12 & 12 & 12 & 12 & 12 & 12 & 12 & 12 & 12 & 12 & 12 & 12 \\
\hline \multirow[t]{3}{*}{$\mathrm{O} 4$} & $\mathrm{CC}$ & -.199 & .174 & .509 & 1.000 & $.577^{*}$ & .341 & .252 & .274 & .206 & $.699^{*}$ & .183 & -.074 \\
\hline & Sig. & .536 & .590 & .091 & & .050 & .279 & .429 & .390 & .521 & .011 & .569 & .819 \\
\hline & $\mathrm{N}$ & 12 & 12 & 12 & 12 & 12 & 12 & 12 & 12 & 12 & 12 & 12 & 12 \\
\hline \multirow[t]{3}{*}{ O5 } & $\mathrm{CC}$ & -.080 & .093 & .536 & $.577^{*}$ & 1.000 & $.596^{*}$ & .305 & .244 & .273 & $.734^{* *}$ & .052 & -.181 \\
\hline & Sig. & .806 & .773 & .072 & .050 & & .041 & .335 & .444 & .391 & .007 & .873 & .574 \\
\hline & $\mathrm{N}$ & 12 & 12 & 12 & 12 & 12 & 12 & 12 & 12 & 12 & 12 & 12 & 12 \\
\hline \multirow[t]{3}{*}{ O6 } & $\mathrm{CC}$ & -.483 & .246 & .573 & .341 & $.596^{*}$ & 1.000 & .071 & -.157 & -.092 & $.647^{*}$ & .341 & -.143 \\
\hline & Sig. & .112 & .442 & .052 & .279 & .041 & & .827 & .625 & .776 & .023 & .278 & .657 \\
\hline & $\mathrm{N}$ & 12 & 12 & 12 & 12 & 12 & 12 & 12 & 12 & 12 & 12 & 12 & 12 \\
\hline \multirow[t]{3}{*}{ O7 } & $\mathrm{CC}$ & $.585^{*}$ & $.586^{*}$ & .398 & .252 & .305 & .071 & 1.000 & .336 & .358 & -.022 & -.368 & .173 \\
\hline & Sig. & .046 & .045 & .200 & .429 & .335 & .827 & & .286 & .253 & .946 & .240 & .590 \\
\hline & $\mathrm{N}$ & 12 & 12 & 12 & 12 & 12 & 12 & 12 & 12 & 12 & 12 & 12 & 12 \\
\hline \multirow[t]{3}{*}{ O8 } & $\mathrm{CC}$ & .285 & -.260 & .302 & .274 & .244 & -.157 & .336 & 1.000 & .496 & .031 & -.121 & .188 \\
\hline & Sig. & .368 & .414 & .340 & .390 & .444 & .625 & .286 & & .101 & .923 & .707 & .558 \\
\hline & $\mathrm{N}$ & 12 & 12 & 12 & 12 & 12 & 12 & 12 & 12 & 12 & 12 & 12 & 12 \\
\hline \multirow[t]{3}{*}{ O9 } & $\mathrm{CC}$ & .302 & .340 & .208 & .206 & .273 & -.092 & .358 & .496 & 1.000 & .070 & .239 & .370 \\
\hline & Sig. & .341 & .280 & .516 & .521 & .391 & .776 & .253 & .101 & & .828 & .455 & .237 \\
\hline & $\mathrm{N}$ & 12 & 12 & 12 & 12 & 12 & 12 & 12 & 12 & 12 & 12 & 12 & 12 \\
\hline \multirow[t]{3}{*}{$\mathrm{O} 10$} & $\mathrm{CC}$ & -.503 & -.125 & .557 & $.699^{*}$ & $.734^{* *}$ & $.647^{*}$ & -.022 & .031 & .070 & 1.000 & .445 & -.449 \\
\hline & Sig. & .095 & 699 & .060 & .011 & .007 & .023 & .946 & .923 & .828 & & .147 & .143 \\
\hline & $\mathrm{N}$ & 12 & 12 & 12 & 12 & 12 & 12 & 12 & 12 & 12 & 12 & 12 & 12 \\
\hline \multirow[t]{3}{*}{ O11 } & $\mathrm{CC}$ & -.446 & -.090 & .253 & .183 & .052 & .341 & -.368 & -.121 & .239 & .445 & 1.000 & -.060 \\
\hline & Sig. & .146 & .781 & .427 & .569 & .873 & .278 & .240 & .707 & .455 & .147 & & .854 \\
\hline & $\mathrm{N}$ & 12 & 12 & 12 & 12 & 12 & 12 & 12 & 12 & 12 & 12 & 12 & 12 \\
\hline \multirow[t]{3}{*}{$\mathrm{O} 12$} & $\mathrm{CC}$ & $.621^{*}$ & .524 & -.236 & -.074 & -.181 & -.143 & .173 & .188 & .370 & -.449 & -.060 & 1.000 \\
\hline & Sig. & .031 & .080 & 460 & .819 & .574 & .657 & .590 & .558 & .237 & .143 & .854 & \\
\hline & $\mathrm{N}$ & 12 & 12 & 12 & 12 & 12 & 12 & 12 & 12 & 12 & 12 & 12 & 12 \\
\hline
\end{tabular}

If the employees who are the bearers of the process are not involved in defining strategies and goals, then they will be unclear to them, and the inability to identify with the defined will negatively affect the efficiency of implementation of both strategies and 
goals. Limitation lack of adequate information system O5 has the highest positive correlation (0.734) with limitation of O10 lack of innovation and continuous learning, and then with O6 inadequate database of customers and suppliers. Significant association with the limitation lack of innovation and lifelong learning (O10). The greatest correlation with other limitations is shown by the O10 limitation, the correlation coefficient with (O40,699 , O5-0,734, O6-0,647), which actually suggests that organizations, when they want to increase their innovation and provide their employees with competitive knowledge and skills through continuous learning, go mostly in two directions. One is the provision of adequate databases and an adequate information system and the other is the efficient management of employees through professional HRM and adequate training. The lack of this significantly limits the implementation of ISO 9001 standards in SMEs. Based on the above, it can be stated that the second hypothesis should be accepted, i.e., that most of the limitations that organizations face in the implementation of ISO 9001 standards are positively correlated with each other.

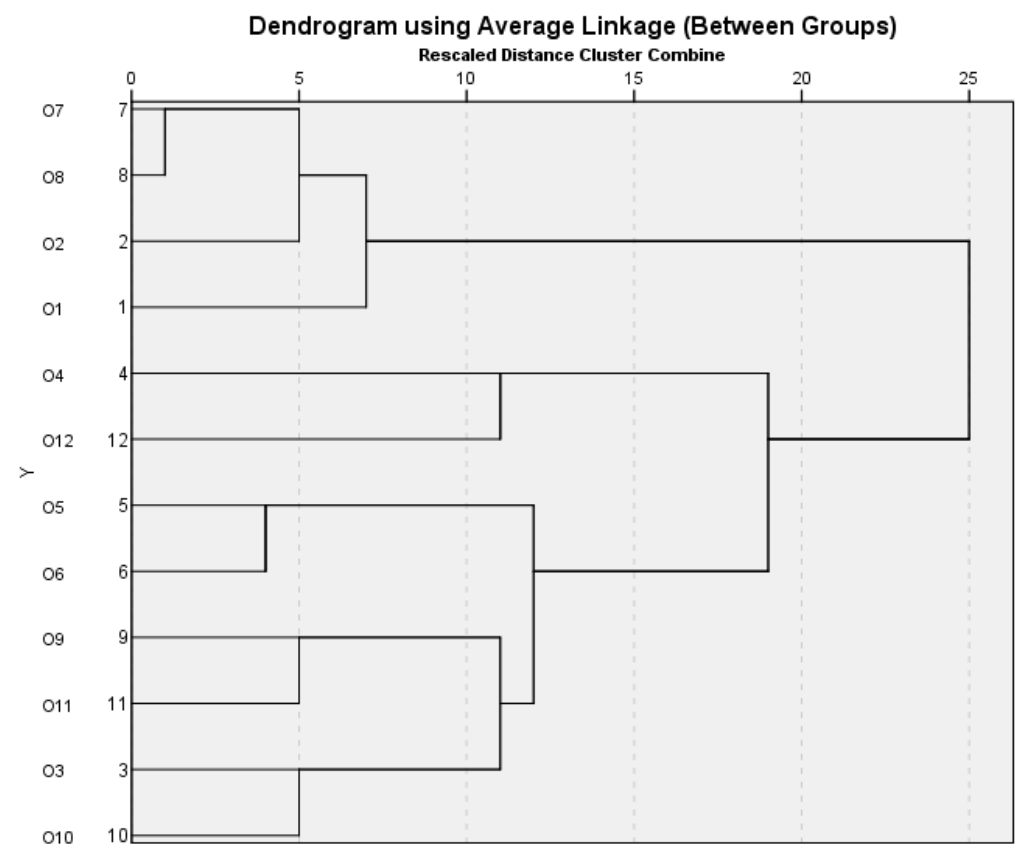

Dendrogram1 Relationship between groups of the limitations Source: Author's calculation

Based on the model of hierarchical cluster analysis, the dendrogram shows the relationship between the limitations as follows: $\mathrm{O} 7, \mathrm{O} 8, \mathrm{O} 2$ and $\mathrm{O} 1$ are closely related, a slightly lower degree of connection is present in the limitations O9, O11, O3 and $\mathrm{O} 10$. There is also a significant correlation between the O5 and O6 limitations, while the O4 and $\mathrm{O} 12$ limitations are poorly interconnected and almost independent of the other limitations. Hierarchical cluster analysis showed that the lack of management commitment to the management system based on ISO 9001:2015 processes and requirements and centralized 
decision-making result in unclear strategy and goals and employees due to non-involvement in defining them show resistance to any changes, including the implementation of ISO 9001. Variables: insufficient knowledge of the process holder, inadequate internal communication, lack of innovation and continuous learning, and insufficient developed skills of employees key to quality within a cluster, show the importance of a strategic approach that includes HRM which will provide employees with the necessary knowledge and skills and improve interpersonal communication.

Despite the fact that the limitation of the non-existence of HRM was assessed with almost the lowest average score by the respondents, cluster analysis and correlation analysis show the need for professional human resource management in companies. The identification of limitations is important due to their connection to problems in fulfilling the requirements of ISO standards. The problems are defined according to the key requirements of ISO 9001:2015, and their connection with the limitations provides an answer to the question which requirements due to the number and type of limitations can be difficult to fulfil.

Respondents were asked to link problems to the limitations previously defined in the Questionnaire. Respondents were able to cite several different limitations as the cause for each problem.

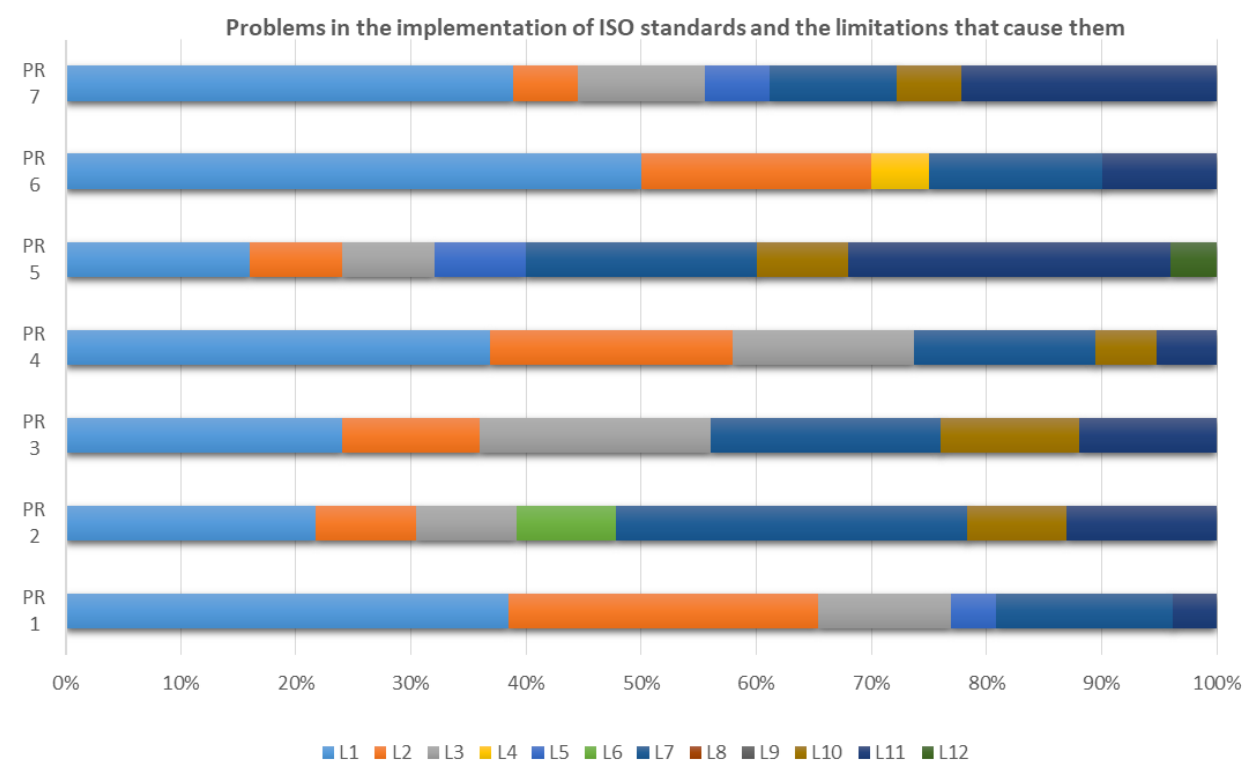

Graph 4 Problems in the implementation of ISO standards and the limitations that cause them Source: Author's calculation

The results of this comparative analysis are the following:

PR 1 - the problem of leadership and commitment of top management to QMS (problem in defining Business Policy, Quality Policy, strategy, quality goals and planning their realization, there is no focus on the user) is mostly influenced by intellectual capital constraints and organizational culture. Due to these limitations, it is difficult for a company to meet all the requirements related to leadership in standards. 
PR 2 - The problem in process design and determining process owners (how to define them and who will manage the process, the problem in defining what documented information is needed) arises mostly due to limitations: non-involvement of employees who are process holders in defining strategies and goals (centralized decision making), inadequate internal communication between employees, also between employee and manager, lack of top management commitment to the management system based on ISO 9001: 2015 processes and requirements, insufficiently developed skills of those employees who are key to quality.

PR3 - The problem of performance evaluation, identification of KPIs processes and their measurement, monitoring and analysis, arises equally due to: lack of top management commitment to the management system based on processes and requirements ISO 9001: 2015, non-involvement of employees in defining strategies and goals (centralized decision making), and insufficient professional knowledge of the process holder in the first place. And then there are the poorly defined company strategies and goals and the lack of innovation and continuous learning.

PR4 - The problem of understanding the organization and its context, identifying stakeholders and their requirements, as well as keeping this information up to date is conditioned by the limitations of human capital and organizational culture.

PR5 - The problem in planning and managing the implementation of operational activities, design and development of products and services and management of outsource processes, products and services is caused by research results mostly due to insufficient capabilities and skills of those employees who are key to quality (creativity, teamwork, critical thinking, emotional intelligence, negotiation, ability to solve complex problems). After this cause, the lack of top management commitment to the management system based on the processes and requirements of ISO 9001: 2015, centralized decision-making and inadequate internal communication between employees, also between employees and managers equally affected the emergence of this problem.

PR6 -The problem in determining responsibilities and authorities for employees and process managers is primarily due to the commitment of management to QMS, and then unclearly defined strategies and goals and inadequate communication between employees and employees and managers.

PR7 - The problem of consistency in the implementation of the process approach (management of documented information and their changes, review by management, internal checks, identification of risks and opportunities, taking measures and control of their implementation) is a consequence of lack of top management commitment to management process based on ISO 9001: 2015, inadequate communication between employees, and between employees and managers, to a lesser extent also insufficient capabilities and skills of those employees who are key to quality.

Based on the above, it can be concluded that the third hypothesis should be accepted, i.e., that the limitations in the implementation of ISO 9001 lead to problems in fulfilling the requirements of ISO standards.

When it comes to the way of solving problems, respondents were given the opportunity to express their agreement or disagreement with the proposed solutions. For each of the proposed solutions, the results of the descriptive statistic analysis show high average score without significant differences in the answers of the respondents. 
Table 5. Descriptive Statistics - Solutions

\begin{tabular}{lccccc}
\hline & $\mathrm{N}$ & Minimum & Maximum & Mean & Std. Deviation \\
\hline $\mathrm{R} 1$ & 12 & 1.00 & 5.00 & 4.3333 & 1.23091 \\
$\mathrm{R} 2$ & 12 & 2.00 & 5.00 & 3.8333 & .93744 \\
$\mathrm{R} 3$ & 12 & 3.00 & 5.00 & 4.3333 & .65134 \\
$\mathrm{R} 4$ & 12 & 3.00 & 5.00 & 4.7500 & .62158 \\
$\mathrm{R} 5$ & 12 & 4.00 & 5.00 & 4.5833 & .51493 \\
$\mathrm{R} 6$ & 12 & 3.00 & 5.00 & 4.3333 & .77850 \\
$\mathrm{R} 7$ & 12 & 2.00 & 5.00 & 3.9167 & .90034 \\
$\mathrm{R} 8$ & 12 & 1.00 & 5.00 & 4.1667 & 1.19342 \\
$\mathrm{R} 9$ & 12 & 1.00 & 5.00 & 3.8333 & 1.11464 \\
$\mathrm{R} 10$ & 12 & 2.00 & 5.00 & 4.1667 & .93744 \\
$\mathrm{R} 11$ & 12 & 4.00 & 5.00 & 4.4167 & .51493 \\
$\mathrm{R} 12$ & 12 & 3.00 & 5.00 & 4.0833 & .66856 \\
$\mathrm{R} 13$ & 12 & 3.00 & 5.00 & 3.9167 & .66856 \\
\hline \multicolumn{5}{c}{ Source: Author's calculation } \\
\end{tabular}

The most important solutions to the defined problems are identified as: R4 - Defining area of implementation of QMS and defined processes and their owners, ensuring management commitment and customer focus (Mean 4.7500, Std. deviation 0.62158), R5 - Providing full involvement of process owners in formulating all necessary documented information, updating them, defining KPIs (Mean 4.5833, Std. deviation 0.51493), R11 Continuous review of documented information through internal checks, with defining corrective measures, control of their implementation (Mean 4.4167, Std. deviation 0.51493). As the least important solutions were evaluated R2 - Adequately defined quality goals and ways of achieving them, and R9 - Adequately defined Quality Policy and communication through the organization.

\section{CONCLUSION}

During the implementation and maintenance of quality management systems according to the requirements of ISO 9001:2015, organizations face many limitations, which if not eliminated during implementation, can only become more complicated and can lead to decertification. The results of the research show that non-material limitations are the dominant obstacle to the implementation of ISO 9001:2015. Also, they are positively correlated with each other and together they can cause problems for companies in fulfilling the requirements of ISO standards. The analysis showed that most problems in fulfilling the requirements of the standard (such as requirements related to leadership, understanding the organization and its context, as well as determining responsibilities and authorities for employees and managers), were actually caused by two human capital limitations (lack of top management commitment and poorly defined strategy and goals). When fulfilling the requirements for process design and determining the process owner, the most problems are caused by centralized decision-making and insufficiently developed skills of employees key to quality and commitment to quality management, which indicates the importance of strategic approach in process design and the need to establish process orientation. Problems can be most effectively solved by clearly defining the area of implementation of quality 
management systems, defining processes and their owners, ensuring management commitment, ensuring full involvement of process owners in formulating all necessary documented information, updating them, defining KPIs for each process. Continuous review of documented information through internal checks, with the definition of corrective measures, and control of their implementation ensure the elimination of problems and fulfilling the requirements of the standard. Although the financial limitation is often cited as an excuse by company managers, the results of this research show the opposite. In this regard, future research should be devoted to a more detailed analysis of the limitations of a non-material nature.

Also, based on the results of the research, managers are suggested to provide the top management training concerning the requirements of the standard at the very beginning of the implementation in order to provide the necessary support for quality management systems. In addition, full involvement of process owners in defining quality strategies and objectives, process design and definition of documented procedures and performances of the processes, as well as their ongoing training to build capacity and capabilities to effectively implement quality management systems should be ensured. In this way, interpersonal communication will be improved and the resistance of employees to change reduced.

\section{REFERENCES}

Anholon, R., Simon Rampasso, I., Cooper Ordonez, R. E., Silva, D.d., Quelhas, O. L. G., \& Leal Filho, W. (2018). Observed difficulties during implementation of quality management systems in Brazilian manufacturing companies. Journal of Manufacturing Technology Management, 29(1), 149-167.

Alsughayir, A. (2014). Barriers to TQM Implementation within a Private Medical Services Organizations in Saudi Arabia. International Journal of Business Administration, 5(3), 117-121.

Bounabri, N., El Oumri, A., Saad, E., Zerrouk, L., \& Ibnlfassi, A. (2018). Barriers to ISO 9001 implementation in Moroccan organizations: Empirical study. Journal of Industrial Engineering and Management, 11(1), 34-56.

Berrouiguet, A. (2013). Barriers to implementing total quality management in Algerian manufacturing organizations. Valahian Journal of Economic Studies. 4(18), 61-66.

Dilawo, R. S., \& Salimi, Z. (2019). Understanding TQM implementation barriers involving construction companies in a difficult environment. International Journal of Quality \& Reliability Management, 36(7), 1137-1158.

Almeida, D., Pradhan, N., \& Muniz Jr, J. (2018). Assessment of ISO 9001:2015 implementation factors based on AHP: Case study in Brazilian automotive sector. International Journal of Quality \& Reliability Management, 35(7), 1343-1359.

Sfakianaki, E., \& Kakouris, A. P. (2020). Obstacles to ISO 9001 certification in SMEs. Total Quality Management \& Business Excellence, 31(13-14), 1544-1564.

Ferreira, L. M. F. R. \& Candido, C. J. F. (2021). Factors influencing firm propensity for ISO 9001 withdrawal: Evidence on decertification tendency and antecedents. International Journal of Production Economics, 233,108024 .

ISO (2020). ISO Survey: The ISO Survey of management system standard certifications 2019. Geneva, Switzerland: ISO Publishing

Lizarraga, M. S., Romero, J. L., Tlapa, D., \& Lopez, Y. B. (2020). ISO 9001 Standard: exploratory analysis in the manufacturing sector in Mexico. Sánchez-Lizarraga et al / Revista DYNA, 87(213), 202-211.

Mohammad Mosadeghrad, A. (2014). Why TQM programmes fail? A pathology approach. The TQM Journal, 26(2), 160-187.

Mohammad Mosadeghrad, A. (2013). Obstacles to TQM success in health care systems. International Journal of Health Care Quality Assurance, 26(2), 147-173.

Othman I., Ghani S., \& Choon, S. (2019). The Total Quality Management (TQM) journey of Malaysian building contractors. Ain Shams Engineering Journal, 11(3), 697-704. 
Polat, G., Damci, A., \& Tatar, Y. (2011). Barriers and benefits of total quality management in the construction industry: Evidence from the Turkish contractors. In 7th Research/Expert Conference with International Participations"QUALITY 2011“, Neum, B\&H, June 1-4, 2011.

Sadikoglu, E., \& Olcay, H. (2014). The effects of total quality management practices on performance and the reasons of and the barriers to TQM practices in Turkey. Advances in Decision Sciences, 17.

Sampaio, P. A., Saraiva, P. M., \& Gomes, A. C. R. (2014). ISO 9001 European Scoreboard: an instrument to measure macroquality. Total Quality Management \& Business Excellence, 25(3-4), 309-318

Talapatra, S., \& Uddin, M. K. (2019). Prioritizing the barriers of TQM implementation from the perspective of garment sector in developing countries. Benchmarking: An International Journal, 26(7), 2205-2224.

Talib, F., \& Rahman, Z. (2015).Identification and prioritization of barriers to total quality management implementation in service industry. The TQM Journal, 27(5), 591-615.

Willar, D., Coffey, V., \& Trigunarsyah, B. (2015). Examining the implementation of ISO 9001 in Indonesian construction companies. The TQM Journal, 27(1), 94-107.

\section{ANALIZA OGRANIČENJA IMPLEMENTACIJE STANDARDA SERIJE ISO SA STANOVIŠTA EKSTERNIH STEJKHOLDERA}

Svrha ovog rada je da se identifikuju ključna ograničenja primene standarda ISO 9001: 2015, njihove korelacije, kao i povezanost sa problemima sa kojima se kompanije susreću. U radu u pregledu literature korišćeni su istraživački radovi drugih istraživača koji se odnose na ograničenja primene ISO standarda. U cilju obezbeđenja svrhe istraživanja, sprovedeno je empirijsko istraživanje. Istraživanje je realizovano metodom anketnog upitnika, na uzorku od 12 ispitanika, konsultanata konsultantskih kompanija za primenu standarda $i$ vodećih ocenjivača akreditovanih sertifikacionih tela za primenu ISO standarda u Srbiji. Korištenje ovog pristupa zasnovanog na eksternim izvorima osigurava određeni nivo objektivnosti. Takođe, iskustvo ispitanika u primeni procesnog pristupa i sertifikaciji različitih organizacija daje potreban kredibilitet $i$ kvalitet samom istraživanju. $U$ radu je identifikovano 12 ograničenja primene ISO 9001. Rezultati istraživanja pokazuju da su nematerijalna ograničenja dominantna prepreka primeni ISO 9001:2015. Ta su ograničenja pozitivno međusobno povezana, tako da kompanijama mogu stvoriti višestruke probleme u ispunjavanju zahteva ISO standarda.

Ključne reči: procesni pristup, ISO 9001, ograničenja, problemi, rešenja, empirijsko istraživanje. 